\title{
Abundance of soil microbial communities and plant growth in agroecosystems and forest ecosystems
}

\author{
Evan Purnama Ramdan ${ }^{1}$, Achmad Yozar Perkasa ${ }^{1 *}$, (D) Abdul Munif ${ }^{2}$, Dwi Astuti ${ }^{3}$, \\ Andini Hanif ${ }^{4}$, Cheppy Wati ${ }^{5}$, Astri Afriani ${ }^{6}$, Nurholis ${ }^{7}$ \\ ${ }^{I *}$ Agrotechnology Dept. Gunadarma University, Depok, Indonesia \\ ${ }^{2}$ Plant Protection Dept. IPB University, Bogor, Indonesia \\ ${ }^{3}$ Indonesian Institute of Sciences, Jakarta, Indonesia \\ ${ }^{4}$ Agrotechnology Dept. University of Muhammadiyah Sumatera Utara, Indonesia \\ ${ }^{5}$ Bogor Agricultural Development Polytechnic, Indonesia \\ ${ }^{6}$ Agrotechnology Dept. Samudra University, Indonesia \\ ${ }^{7}$ Applied Reseacrh Institute of Agricultural Quarantine, Indonesia \\ Corresponding author: achmad_yozar@staff.gunadarma.ac.id
}

\begin{abstract}
The objective of this study was to review natural ecosystems and agroecosystems to compare the abundance of soil microbial communities and also plant growth. This study used a random block design method, each soil from both ecosystems is planted with corn and string beans. Each treatment is repeated three times and arranged in random block design. At the end of the study, head height, root display and leaf count were calculated. The results showed that soils from agroecosystems had greater microbial abundance and good plant growth responses. The results showed that agroecosystems are ecosystems that have an abundance of microbial communities that are the most good compared to forest ecosystems. This has an impact on good growth responses in agroecosystems compared to forest ecosystems.
\end{abstract}

Keywords: Agriculture ecosystem, plant growth promoting agents, natural ecosystem

\section{Introduction}

Healthy soils are the capacity of soils to function, within the boundaries of natural and managed ecosystems, to maintain crop productivity, maintain water and air quality, support human welfare, and provide habitat for biodiversity (Doran and Zeiss, 2000; Gugino et al., 2009). Human impacts on soil health largely arise from the need to meet the growing food, fiber and fuel needs of the population. In recent decades significant efforts have been made to increase agricultural productivity through increased fertilization and application of pesticides, increased irrigation, land and crop management, and largescale land conversion (Tilman et al., 2001). 
Recently, awareness and concern have begun to emerge that agricultural intensification is putting tremendous pressure on the capacity of soils to maintain other functions that lead to large-scale ecosystem degradation and long-term loss of productivity (Foley et al., 2005; Vitousek et al., 2009). For example, the conversion of natural ecosystems into agricultural land has caused huge environmental costs, including desertification, increased greenhouse gas emissions, decreased organic matter in the soil, loss of biodiversity, and changes in biogeochemical and hydrological cycles (Balmford et al., 2005). Modern agriculture thus faces major challenges not only in terms of ensuring global food security by increasing crop yields but also reducing environmental costs especially in the context of a changing environment and increasing competition for land, water and energy (Chen et al., 2014). Therefore, this study aims to examine the natural ecosystems represented by pine forests and agroecosystems to compare the abundance of soil microbial communities and also plant growth. The hypothesis are microbes in forest soils are higher than in agroecosystem soils because forest land is still virgin and there is no additional input from humans

\section{Material and Methods}

\section{Site Properties}

The experiment was conducted at the pine forest ecosystems Mount Halimun Salak National Park, sub district Pamijahan Bogor district, West Java -6.689177, 106.680534 and Cikabayan Experimental Station, Dramaga Campus of IPB University, Bogor district West Java -6.550665, 106.715212.

\section{Material}

The materials used were soil samples from pine forest ecosystems were taken from the Mount Halimun Salak National Park, Bogor, and soils from agroecosystems from the Cikabayan Experimental Station, Dramaga Campus of IPB, Bogor, sweet corn seed varieties of bonanza and peanut varieties of zebras, sterile aquades, Pikovskaya media, Martin jelly and TSA. The equipment used is equipment for analyzing soil properties in the field and laboratories, stationery, and a computer set.

\section{Method}

Time and Place of Implementation

The research activities were carried out from September to December 2019 in the Experimental Station and Education Laboratory, Plant Protection Department, Faculty of Agriculture, Dramaga Campus of IPB.

Planting Media Preparation

The planting media used in this study were soil samples with soil depth $0-20 \mathrm{~cm}$ latosol type soil, clay soil texture with $\mathrm{pH}$ 6, this soil belongs to the type of Mediterranean land with moderate sensitivity to erosion from pine forest ecosystems taken from the Mount Halimun Salak National Park, Bogor, and soil from agroecosystems latosol type soil with soil depth $0-20 \mathrm{~cm}$, clay soil texture with $\mathrm{pH} 6$ from the Cikabayan Experimental Station, Dramaga Campus of IPB, Bogor. Each soil sample is then prepared in a planting tub with a size of $38 \times 30 \times 15 \mathrm{~cm}$. 


\section{Planting of planting material}

The planting material used consists of sweet corn seeds of bonanza varieties and peanut varieties of zebra. Each tub is planted with 5 seeds. Then maintained until the age of 4 weeks with treatment in the form of watering and weeding.

Plant growth measurement

At the end of the study it was observed that plant growth included 1) the height of the canopy measured from the ground surface to the highest canopy, 2) the number of leaves, and 3) the length of the roots measured from the base of the stem to the tip of the root.

Population Observation and Enumeration of Soil Microbes

Each soil sample was taken from each treatment as much as $1 \mathrm{~g}$ and put in $10 \mathrm{~mL}$ of sterile aquades. Then it is diluted serially until dilution $10^{-4}$. Soil suspensions at dilutions $10^{-3}$ and $10^{-4}$ were taken 0.1 $\mathrm{mL}$ and grown on Pikovskaya, Martin jelly, and TSA media by the scatter method. Microbial enumaration is done by calculating the total plate count based on BSN (2006) using the formula:

$$
N=\frac{\sum c}{[(1 \times n 1)+(0.1 \times n 2] x(d)}
$$

The items in the formula refer to:

$\mathrm{N}=$ Number of product colonies, expressed in CFU per $\mathrm{mL}$

$\sum \mathrm{c} \quad=$ Number of colonies in all plates was counted

$\mathrm{n} 1=$ Number of plates in the first dilution is calculated

$\mathrm{n} 2=$ Number of plates in the second dilution is calculated

$\mathrm{d}=$ The first dilution is calculated

Data analysis

This study used a randomized block design with 3 replications. The data obtained were processed using SAS program version 9.1. The treatments that showed significant differences were further tested by Duncan's test at $5 \%$ level.

\section{Results}

Abundance of Soil Microbial Communities

Exploration results of soil microbial communities from agroecosystems and forests found bacteria, fungi, and phosphate solubilizing bacteria in each treatment (Table 1). However, the abundance of soil communities tends to be more common in soils from agroecosystems than in pine forest ecosystems. Meanwhile, soil from agroecosystems planted with peanuts showed the greatest abundance of soil microbes, namely bacteria of $2.74 \times 105 \mathrm{CFU} \mathrm{mL} \mathrm{m}^{-1}$, fungi of $1.86 \times 104$, fungi of $\mathrm{CFU} \mathrm{mL} \mathrm{m}^{-1}$, phosphate solubilizing bacteria of $2.74 \times 105 \mathrm{CFU} \mathrm{mL}^{-1}$. Meanwhile, the smallest abundance of microbes is shown by soil from pine forest ecosystem planted with peanuts, with a number of bacteria of $6.27 \times 103 \mathrm{CFU}$

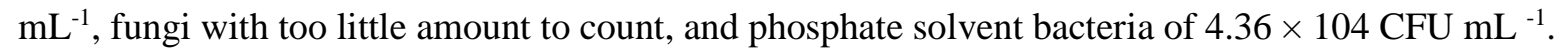


Table 1. Soil microbial populations in the treatment of agroecosystems and pine forests.

\begin{tabular}{ccccc} 
No & Treatments & $\begin{array}{c}\text { Bacteria } \\
\left(\mathrm{CFU} \mathrm{mL} \mathrm{mL}^{-1}\right.\end{array}$ & $\begin{array}{c}\text { Fungi } \\
(\mathrm{CFU} \mathrm{mL}\end{array}$ & $\begin{array}{c}\text { Phosphate Solvent Bacteria } \\
\left(\mathrm{CFU} \mathrm{mL}^{-1}\right)\end{array}$ \\
\hline 1 & $\mathrm{~T}_{1} \mathrm{E}_{1}$ & $9.04 \times 10^{4}$ & $\mathrm{TSUD}$ & $2.61 \times 10^{4}$ \\
2 & $\mathrm{~T}_{2} \mathrm{E}_{1}$ & $2.74 \times 10^{5}$ & $1.86 \times 10^{4}$ & $2.74 \times 10^{5}$ \\
3 & $\mathrm{~T}_{1} \mathrm{E}_{2}$ & $1.97 \times 10^{4}$ & $6.56 \times 10^{3}$ & $4.36 \times 10^{4}$ \\
4 & $\mathrm{~T}_{2} \mathrm{E}_{2}$ & $6.27 \times 10^{3}$ & TSUD & $4.36 \times 10^{4}$ \\
\hline
\end{tabular}

Remarks : T1E1 = corn plants on agroecosystem soils, T2E1 = peanut plants on agroecosystem soils, T1E2 = corn plants on exocytes of pine forests, T2E2 = peanut plants on soils of pine forest ecosystems.

Growth response of corn and peanut plants

Based on plant growth parameters, the best ecosystem for maize and long bean growth is agroecosystem compared to pine forest ecosystem (Table 2). The results of the analysis of variance showed that the two plants growing media from the agroecosystem had a significant influence on the height of the canopy compared to the pine forest ecosystem. The difference in height of the canopy between corn in the agroecosystem and forest ecosystem planting media was $30.75 \mathrm{~cm}$, and the difference in the canopy between the peanuts in the agroecosystem and forest ecosystem planting media was $9.85 \mathrm{~cm}$. Meanwhile, for the root length variation, in the long bean plant based on the analysis of variance, there was no real effect of the use of growing media from both ecosystems.

Table 2. Response of growth of corn and peanuts in planting media from different ecosystems

\begin{tabular}{ccccc}
\hline No & Treatments & Canopy Height & Root Length & Number of Leaves \\
\hline 1 & $\mathrm{~T}_{1} \mathrm{E}_{1}$ & $49.40 \mathrm{a}$ & $44.76 \mathrm{a}$ & $4.80 \mathrm{c}$ \\
2 & $\mathrm{~T}_{2} \mathrm{E}_{1}$ & $30.58 \mathrm{~b}$ & $36.87 \mathrm{a}$ & $15.60 \mathrm{a}$ \\
3 & $\mathrm{~T}_{1} \mathrm{E}_{2}$ & $18.65 \mathrm{c}$ & $6.93 \mathrm{~b}$ & $3.67 \mathrm{c}$ \\
4 & $\mathrm{~T}_{2} \mathrm{E}_{2}$ & $20.73 \mathrm{c}$ & $44.33 \mathrm{a}$ & $10.93 \mathrm{~b}$ \\
\hline
\end{tabular}

Remarks : T1E1 = corn plants on agroecosystem soils, T2E1 = peanut plants on agroecosystem soils, T1E2 = corn plants on exocytes of pine forests, T2E2 = peanut plants on soils of pine forest ecosystems. The numbers in the same column followed by the same letter are not significantly different at the 5\% test level (Duncan's test).

However, the corn planted in agroecosystem planting media showed a significant effect on increasing root length compared to pine forest ecosystem planting media by selecting root length increase of 37.83 $\mathrm{cm}$. In the parameters of the number of leaves, the only real effect is on the planting of peanuts. The results of the analysis showed that the agroecosystem planting media showed a real effect on the number of peanut leaves compared to the pine forest ecosystem.

\section{Discussion}

Soil microbial communities show that their abundance is high in agroecosystems compared to forest ecosystems. Agroecosystem which is an artificial ecosystem occurs practices of soil management, crop rotation, periodic fertilization; and the application of pesticides resulting in temporal and spatial changes in the physical and chemical properties of soils in agricultural systems (Carbonetto et al., 2014). Such agroecosystems represent a rapidly fluctuating environment with highly variable resource gradients and create greater bio-physical and chemical heterogeneity compared to forest ecosystems, thus providing a variety of gaps for microbial growth (Trivedi et al. 2016). Microbial communities in natural systems 
may be limited by the availability of nutrients and therefore the addition of fertilizers can allow colonization by new species from regional ponds (Crowther et al., 2014; Figuerola et al., 2015).

In this study, the composition of soil microbes found in abundance in agroecosystem soils correlated with the growth parameters of corn and peanuts in soil media from agro-systems. The presence of microbial communities on the soil has several roles including as biological fertilizer, providing phosphorus to be absorbed by plants, nitrogen fixation, siderophor production, and phytohormone production (Mehmood et al., 2018). The presence of microbes in the form of bacteria from the PGPR group in the soil not only rapidly colonizes the rhizosphere soils and enhances the absorption ability of plant nutrients but also is beneficial in suppressing disease through various mechanisms. One of the nutrients that plants need is phosphorus.

Phosphorus is an important nutrient taken from the soil by plants in the form of phosphate anions (Nautiyal et al., 2000). Because of its highly reactive nature, phosphate anions can be obtained by plants with cation precipitation $\left(\mathrm{Al}_{3}{ }^{+}, \mathrm{Mg}_{2}{ }^{+}\right)$. The availability and unavailability of phosphorus for plants depends on the quality of the soil because phosphorus is very insoluble in the soil, therefore only a limited amount of phosphorus is available for plants (Yadav and Dadarwal, 1997). It has been documented by many researchers that Hydroxyapatite, di-calcium phosphate, rock phosphate and tricalcium phosphate are transformed into soluble forms by various species of beneficial bacteria present in the soil and these beneficial bacterial species are called phosphate solvent bacteria (PSB) (Chen et al., 2006; Rodríguez and Fraga, 1999). Various mechanisms are followed by PSB to dissolve phosphates that are not available including the release of enzymes and the production of certain acids (Greiner et al., 2001). PSB inoculation not only increases plant growth parameters but also significantly increases overall crop yields (Moura et al., 2001).

\section{Conclusion}

The results showed that agroecosystems are ecosystems that have an abundance of microbial communities that are the most good compared to forest ecosystems. This has an impact on good growth responses in agroecosystems compared to forest ecosystems. The limitation in this study are, this study has not been able to identify the type and function of microbes, but this study has implications that can determine the level of soil health through the observed abundance of microbes.

\section{References}

Balmford, A., Bennun, L., Brink, B. T., Cooper, D., Cote, I. M., Crane, P. (2005). The convention on biological diversity's 2010 target. Science 307, 212-213. doi: 10.1126/science.1106281.

Badan Standar Nasional (BSN). 2006. Cara Uji Mikrobiologi- Bagian 3: Penentuan Angka Lempeng Total (ALT) pada Produk Perikanan. Badan Standar Nasional. Jakarta (Indonesian Language).

Carbonetto, B., Rascovan, N., Álvarez, R., Mentaberry, A., and Vázquez, M. P. (2014). Structure, composition and metagenomic profile of soil microbiomes associated to agricultural land use and tillage systems in Argentine Pampas. PLoS ONE 9:e99949. doi:10.1371/journal.pone.0099949

Chen, Y.P., Rekha, P.D., Arun, A.B., Shen, F.T., Lai, W.A., Young, C.C., 2006. Phosphate solubilizing bacteria from subtropical soil and their tricalcium phosphate solubilizing abilities. Applied soil ecology 34, 33-41.

Chen, X., Cui, Z., Fan, M., Vitousek, P., Zhao, M., Ma, W., et al. (2014). Producing more grain with lower environmental costs. Nature 514, 486-489. doi: 10.1038/nature13609.

Crowther, T. W., Maynard, D. S., Leff, J. W., Oldfield, E. E., McCulley, R. L., Fierer, N., et al. (2014). Predicting the responsiveness of soil biodiversity to deforestation: a cross-biome study. Glob. Change Biol. 20, $2983-2994$. doi: $10.1111 / \mathrm{gcb} .12565$

Doran, J. W., and Zeiss, M. R. (2000). Soil health and sustainability: managing the biotic component of soil quality. Appl. Soil Ecol. 15, 3-11. doi: 10.1016/S0929-1393(00)00067-6. 
Figuerola, E. L., Guerrero, L. D., Türkowsky, D., Wall, L. G., and Erijman, L. (2015). Crop monoculture rather than agriculture reduces the spatial turnover of soil bacterial communities at a regional scale. Environ. Microbiol. 17, 678-688. doi: 10.1111/1462-2920.12497

Foley, J. A., DeFries, R., Asner, G. P., Barford, C., Bonan, G., Carpenter, S. R., et al. (2005). Global consequences of land use. Science 309,570-574. doi: 10.1126/science.1111772

Greiner, R., Alminger, M.L., Carlsson, N.-G., 2001. Stereospecificity of myo-inositol hexakisphosphate dephosphorylation by a phytate-degrading enzyme of baker's yeast. Journal of agricultural and food chemistry 49 , 2228-2233.

Gugino, B. K., Idowu, O. J., Schindelbeck, R. R., van Es, H. M., Wolfe, D. W., Moebius, B. N., et al. (2009). Cornell Soil Health Assessment Training Manual, 2nd Edn. Geneva: Cornell University.

Mehmood U, Inam-ul-Haq, Saeed M, Altaf A, Azam F. 2018. A brief review on plant growth promoting rhizobacteria (PGPR): a key role in plant growth promotion. Plant Protection 2(2):77-82.

Moura, D.S., Bergey, D.R., Ryan, C.A., 2001. Characterization and localization of a woundinducible type I serinecarboxypeptidase from leaves of tomato plants (Lycopersicon esculentum Mill.). Planta 212, 222-230.

Nautiyal, C.S., Bhadauria, S., Kumar, P., Lal, H., Mondal, R., Verma, D., 2000. Stress induced phosphate solubilization in bacteria isolated from alkaline soils. FEMS Microbiology Letters 182, 291-296

Tilman, D., Fargione, J., Wolff, B., D’Antonio, C., Dobson, A., Howarth, R., et al. (2001). Forecasting agriculturally driven global environmental change. Science 292, 281-284. doi: 10.1126/science.1057544.

Rodríguez, H., Fraga, R., 1999. Phosphate solubilizing bacteria and their role in plant growth promotion. Biotechnology advances 17, 319-339.

Trivedi P, Delgado0Baqruerizo M, Anderson IC, Singh BK. 2016. Response of soil properties and microbial communities to agriculture: implications for primary productivity and soil health indicators. Frontiers in Plant Science 7: 1-13.

Vitousek, P. M., Naylor, R., Crews, T., David, M. B., Drinkwater, L. E., Holland, E., et al. (2009). Nutrient imbalances in agricultural development. Science 324:1519. doi: 10.1126/science.1170261

Yadav, K.S., Dadarwal, K.R., 1997. Phosphate slubilization and mobilization through soil microorganisms, Biotechnological approaches in soil microorganisms for sustainable crop production, pp. 293-308.

Submitted: 01.04.2020 Accepted: 16.06.2020 